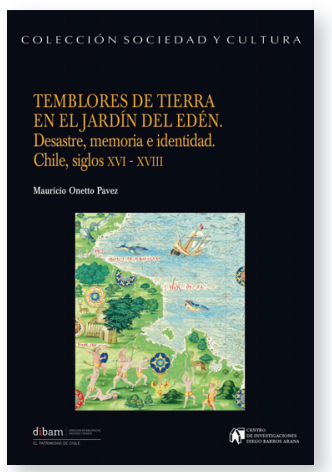

\title{
Mauricio Onetto Pavez. Temblores de tierra en el jardín del Edén. Desastre, memoria e identidad. Chile, siglos XVI - XVIII.
}

\author{
Santiago de Chile: Ediciones de la Dirección de Bibliotecas, \\ Archivos y Museos - DIBAM, Centro de Investigaciones \\ Diego Barros Arana. 2017. 472 p.
}

\author{
Enrique Aliste ${ }^{1}$
}

Mauricio Onetto nos presenta su reciente obra "Temblores de tierra en el jardín del Edén. Desastre, memoria e identidad. Chile, siglos XVI - XVIII", un trabajo muy serio, sistemático, riguroso y detallado que explora las catástrofes telúricas que han visitado esta tierra por siglos. Se concentra para ello entre los siglos XVI y XVIII, ofreciéndonos un relato rico en detalles y en elementos críticos que vale la pena detenerse a reflexionar, especialmente cuando ellos atañen a aspectos que tocan el difícil campo de aquello que llamamos la identidad.

Lo relevante del trabajo del Dr. Onetto es el ser capaz de ir mucho más allá de la crónica, que es lo que normalmente arriesgan algunos trabajos con esta perspectiva. Y por el contrario, en este texto se aventuran verdaderas baterías de hipótesis que buscan explorar elementos de sentido contenidos en la producción discursiva sobre las catástrofes, con especial acento en la dimensión telúrica.

El libro se organiza en tres partes, en donde la primera explora y se pregunta sobre los orígenes del desastre en Chile. Lo interesante de esta parte del trabajo es la de ahondar en elementos genealógicos referidos a los temores, la "mala fama", la inseguridad, las ruinas, e incluso de los miedos alimentados por las insurrecciones indígenas que afectaron a estas tierras del sur del mundo; en definitiva, hay una indagatoria en torno a los múltiples orígenes de la noción desastrosa de la tierra de Chile, lo que luego es retomado en perspectiva para discutir en torno a la idea de la condición trágica que marca un sello distinguible para referirse al destino que ha tenido la nación con el devenir del tiempo.

La segunda parte explora ya en más detalle el rol protagónico de los movimientos telúricos en la consolidación de este discurso catastrófico, visto en ámbitos múltiples y en la incidencia sobre ámbitos de decisión y en las cotidianidades contenidas en las prácticas sociales. Tal como se señala en la introducción, se desarrolla la tesis sobre cómo se transmitieron las expectativas respecto de estos territorios. 
La tercera parte busca explorar ya de un modo más decidido cómo estas nociones y discursos transmitidos en torno a la condición catastrófica, se propagó en el tiempo por medio de representaciones de diversa naturaleza, y que fueron en cierta medida eternizando esta noción en la memoria colectiva.

En atención a lo anterior, varios elementos merecen ser reflexionados en torno a la provocadora lectura que ofrece el autor. Entre ellos, por ejemplo, los referidos a las semánticas y nociones que se comienzan a emplear ya tempranamente con la conquista. Por ejemplo, el que el peso de la palabra catástrofe encuentra su lugar en la historia nacional con una curiosa falta de protagonismo, hasta que el presente trabajo nos lo muestra de una manera extraordinariamente diferente. En tal sentido, vale la pena recordar el ensayo de Lucien Febvre referido a la palabra "civilización", especialmente cuando el historiador francés se detiene en explicar el modo en que una palabra de uso tan común y frecuente en la historia, juega en campos semánticos tan diferentes a lo largo del tiempo; en el contexto de la presente obra, Onetto viene a revisitar de un modo fascinante el principio de la mutación temporal de los significados y, con ello, el modo en que los discursos van incidiendo en las definiciones que marcan los territorios de estas latitudes. La alusión a la obra de Rolando Mellafe, por cierto, es no sólo un acierto sino además una suerte de homenaje que es capaz de trascender en torno a una de las tesis que propone este trabajo: ¿hay rasgos identitarios en el sello que imponen las catástrofes a Chile?

Al respecto, Fernand Braudel escribió un comentario crítico a la obra de Benjamín Subercaseaux "Chile, o una loca geografía", y que tituló "Chile, aquella locura geográfica", publicado en 1948 en la famosa revista Anales. Uno de los elementos que destaca en dicha reseña es precisamente un aspecto que la obra de Mauricio Onetto viene a discutir con gran riqueza y perspectiva: ¿qué es o en qué radica la condición trágica que trae el legado telúrico a Chile? Braudel, ni más ni menos, señala textualmente refiriéndose a la obra de Subercaseaux y nuestro país como "el país más trágico de América. Ello quiere decir, sobretodo, el más humano..." o también "que cada sufrimiento obliga al hombre a reaccionar y readaptarse".

En la medida en que se avanza en la fascinante lectura de la obra de Onetto, resulta imposible no recordar también el maravilloso e ineludible trabajo de Armando Roa y el gran Jorge Teillier titulado "La invención de Chile", en donde en una magnífica colección de pasajes, textos, poemas y relatos de escritores de fama universal y que jamás pisaron esta tierra, como H. Melville, B. Brecht, E. Allan Poe, J. Verne, J. Conrad, T. Mann, Lope de Vega, André Breton, Francisco de Quevedo, el mismo Von Kleist que trabaja Onetto en este libro, entre otros, dan cuenta de ella con prolijos detalles y en donde, probablemente, lo más frecuente es la tragedia, la dificultad, la catástrofe, el rigor, lo que da cuenta de ese Chile imaginado a través de los textos y crónicas tantas veces transmitidos, tal y cual nos lo relata y analiza en detalle Mauricio Onetto en su trabajo.

Y para ello nos remonta a crónicas, discursos, narrativas que van demarcando un derrotero semántico muy claro y que, en estos actos de reproducción de ciertas representaciones, avanzan hacia una comprensión del fenómeno telúrico más allá del sentido clásico con el que normalmente se trata el tema que nos expone. De hecho, es muy interesante cuando Onetto nos señala: "que el acontecimiento en sí mismo no es suficiente para lograr una comprensión total sobre él y que sus dimensiones no se leen desde un único territorio ni de forma singular" (Onetto, 2017: 333). 
En torno a esta tesis de Onetto, de reproducir ciertas retóricas y un modo particular de escribir la catástrofe, vale la pena visitar la obra de Maurice Blanchot, "La escritura del desastre". Una frase inicial de dicha obra es oportuna y fascinante en el contexto del libro que hoy nos convoca y dice así: "El desastre lo arruina todo al tiempo que deja todo tal cual" (Blanchot, 2010: 7).

Y qué mejor ejemplo para ello que el relato de Horacio Lara Marchant, con ocasión de la celebración de los 50 años del terremoto y maremoto de 1835 en Concepción, que escribió el libro "La ciudad mártir" publicado en 1886. En este trabajo, es fascinante la construcción que hace el autor de la permanente seguidilla de infortunios y desgracias que afectaban a la ciudad de Concepción. En uno de sus relatos inquiere:

"García Hurtado de Mendoza era el ángel tutelar del destino que venía a salvar de tantas penalidades a la desventurada Concepción.

Mediante él y la marcha triunfal de sus huestes presenció Arauco atónito, desde las márgenes del Bio-Bío (hasta) el rápido Cautín; el atrevido indígena contúvose, un tanto, en sus empresas de exterminio.

Concepción respiró un instante en las dulzuras de la paz y el trabajo. Pero si libre estaba del rayo destructor de la guerra, principiaba para ella una nueva odisea: la de los cataclismos: desconocidos fenómenos para sus habitantes.

Los elementos exterminadores de las sangrientas contiendas habían concluido y empezaban las leyes de la naturaleza a conjurarse contra su tranquilidad y su fortuna" (Lara Marchant, [1886] 1998: 38-39)

Lo que hay en el relato de Horacio Lara Marchant es precisamente lo que Mauricio Onetto explora y busca trabajar en mayor profundidad analítica: ¿Qué mueve a leer lo telúrico en este permanente tono trágico, desastroso y dramático, cuando se trata de un fenómeno que tantas veces ha visto remecer las raíces de esta tierra? Porque lo fascinante que hay en la crónica de Lara Marchant es el modo de escribir la catástrofe. Tal como se lee en Blanchot, la escritura del desastre tiene cierta estructura, código y morfología que queda en los registros y que mueve a las formas de leer luego los episodios venideros. Por ello es que el texto de Onetto es una provocación fascinante a cuestionarse las categorías de observación construidas a lo largo de nuestra historia moderna. ¿De qué manera se han construido estos relatos que finalmente, son los que transmiten culturalmente esta experiencia? Allí por lo mismo, la pertinencia y oportunidad con que se articula la presente obra con la rica herencia de P. Ricoeur. Destacar y reconocer la articulación entre memoria, historia y olvido en el trabajo elaborado por Onetto es también un acierto que merece ser destacado, pues abre la puerta a entender claves en el modo de trabajar hoy el tema de la catástrofe en nuestro país. Y en esto, recordar algunos pasajes de la crónica de Darwin indudablemente llevan a darle mayor relevancia a las líneas que ha elaborado Onetto sobre los alcances de esta condición telúrica en nuestra tierra. A propósito del mismo terremoto que homenajea Lara Marchant, Darwin escribía:

“Las dos ciudades (Concepción y Talcahuano) presentan el más terrible espectáculo, pero al mismo tiempo el más interesante que jamás me haya sido dado contemplar (...) las ruinas estaban tan completamente entremezcladas que no podía creerse que aquellos amontonamientos de restos habían servido de moradas (...). En suma no hubo sino un centenar de víctimas, gracias a la invariable costumbre que se tiene de lanzarse fuera de las casas así 
que se nota que el suelo tiembla. En Concepción, cada fila de casas, cada mansión aislada, formaba un montón de ruinas bien distinto; en Talcahuano, al contrario, la ola que había seguido al terremoto y que inundó la ciudad no había dejado al retirarse sino un confuso montón de ladrillos, tejas y vigas, y aquí y allá alguna pared aun en pie (...).

Después de haber visto Concepción, confieso me es difícil comprender cómo pudo escapar de la catástrofe el mayor número de sus habitantes (...)" (Darwin, 1995)

Por su parte, Henri-Pierre Jeudy elabora en 1990 una tesis interesante que publica en un libro titulado "El deseo de catástrofe" para referirse, no obstante, a episodios más recientes respecto de temáticas que abordan el devenir de nuestro planeta, anclado en el uso de las imágenes y discursos sobre la idea del miedo, de lo peor por venir, de la inseguridad, la catástrofe, en definitiva. Levanta la tesis de cómo estos escenarios de búsqueda de control sobre los riesgos, han permitido una suerte de juego perverso que lleva a cierto goce con la catástrofe, con su sola idea y el modo en que el uso de este concepto alimenta una parte de la sociedad actual.

Casi al final, me permito un momento especial para destacar el acierto en abordar la producción artística literaria como uno de los puntos más interesantes. Y nos deja una mirada muy particular que ayuda a la comprensión respecto de cómo la reproducción de ciertos imaginarios que han persistido a través del tiempo, permiten al mismo tiempo dejar un sello que marca el modo en que se comprende la catástrofe en la sociedad que la vive. Hoy podríamos hacer un símil y examinar la importancia y dimensión que ha adquirido el humor en estas materias. Queda lanzada la invitación a partir del trabajo de Onetto, para explorar desde una dimensión historiográfica el rol del humor para enfrentar, entender, asimilar y significar la catástrofe telúrica en Chile por estos días.

Para concluir, a propósito de catástrofe, apenas unas palabras referidas a la obra de Svetlana Alexiévich, Premio Nobel de Literatura 2015, que en su libro "Voces de Chernóbil" señala:

“Es tan fácil deslizarse a la banalidad. A la banalidad del horror... Pero yo miro a Chernóbil como al inicio de una nueva historia; Chernóbil no solo significa conocimiento, sino también preconocimiento, porque el hombre se ha puesto en cuestión con su anterior concepción de sí mismo y del mundo. Cuando hablamos del pasado o del futuro, introducimos en estas palabras nuestra concepción del tiempo, pero Chernóbil es ante todo una catástrofe del tiempo. Los radionúclidos diseminados por nuestra Tierra vivirán cincuenta, cien, doscientos mil años. Y más. Desde el punto de vista de la vida humana, son eternos. Entonces, ¿qué somos capaces de entender? ¿Está dentro de nuestras capacidades alcanzar y reconocer un sentido en este horror del que seguimos ignorándolo casi todo?"

Traigo a colación estas reflexiones de la escritora bielorrusa por un aspecto que toca insistentemente la obra de Mauricio Onetto: ¿Cómo debemos reflexionar y asimilar el paso del tiempo cuando hablamos y queremos entender socialmente, colectivamente, desde nuestra idea de memoria colectiva, lo que conlleva la idea de catástrofe telúrica en nuestra tierra? La invitación está efectuada. 


\section{Referencias bibliográficas}

ALEXIÉVICH, S. Voces del Chernóbil. Madrid: Ed. Debate, 2016.

BLANCHOT, M. La escritura del desastre. Madrid: Ed. Trotta, 2015.

BRAUDEL, F. Chili, cette folie géographique. Annales. Économies, Sociétés, Civilisations. 1948, 3e année, Nº, p. 443-446.

DARWIN, C. Darwin en Chile (1832-1835). Viaje de un naturalista alrededor del mundo. Edición preparada por David Yudilevich Levy y Eduardo Castro Le-Fort. Santiago de Chile: Editorial Universitaria, 1995.

FEBVRE, L. Civilisation: le mot et l'idée. En: FEBVRE, L. Civilisation. Evolution d'un mot et d'un groupe d'idées". Paris: Ed. La Renaissance du Livre, 1930, p.1-55.

JEUDY, H.P. Le désir de catastrophe. Belval: Ed. Circé, 2010.

LARA MARCHANT, H. La ciudad trágica. Concepción: Imprenta de la Revista del Sur, 1998.

ROA, A. y TEILLIER, J. La invención de Chile. Santiago de Chile: Editorial Universitaria, 1993. 
